Balog Piroska* - Dégi L. Csaba

\title{
A CSALÁdI TÁMOGATOTTSÁG SZEREPE A DAGANATOS NÓK PSZICHOSZOCIÁLIS SÉRÜLÉKENYSÉGÉNEK CSÖKKENTÉSÉBEN
}

Célkitüzés: A pszichoszomatikus szakirodalom hangsúlyozza a társas támogatottság szerepét a krónikus betegségekkel való megküzdésben. A családi kapcsolatok minóségével, a családi támogatottság szerepével sokkal kevesebb tanulmány foglalkozik - tanulmányunkban ezek vizsgálatát túztük ki célul.

Módszer: A Csíkszeredai Megyei Kórház Sebészeti Osztályán mútött nóket vizsgáltuk. 30 jóindulatú (benignus) melldaganattal, 30 rosszindulatú (malignus) melldaganattal, és 30 vakbélgyulladással mútött nôt interjúvoltunk meg. A vizsgált nók életkora nem különbözött szignifikánsan. A rosszindulatú daganatos betegek leginkább az alacsony szocio-ökonómiai státusúak köréból kerültek ki. A kérdőívben szerepeltek a családi támogatottságot, a stressz-szintet, a szorongást, valamint a mútéttel kapcsolatos optimizmust, és az információ igénylését mérô skálák.

Eredmények: A legmagasabb volt a szorongás-, illetve stressz-szint a malignus melldaganattal mútétre váró nók körében. A családi támogatottság fontos szerepet játszott e betegek stressz- és szorongásszintjének csökkentésében, valamint a mútéttel kapcsolatos optimizmus növelésében és az igényelt tájékoztató információ mennyiségében is.

Konklúzió: A családi kapcsolatok minôsége, a beteg családi támogatottsága fontos szerepet játszik a mútéttel kapcsolatos stressz- és szorongásszint alakulásában, és minél magasabb az átélt stressz, ennek csökkentésében annál fontosabbá válik a családi támogatás.

Kulcsszavak: daganatos nók, stressz- és szorongásszint, optimizmus, információ igénylése, családi támogatottság

A daganatos betegségek bio-pszicho-szociális rendszerben való vizsgálatáról, illetve a genetikai, biológia, lélektani és társas környezeti tényezók összhatásáról az onkogenezisben és prognózisban, jelenleg, 30 év alatt kivitelezett, 70 prospektív jellegú pszichoonkológiai kutatás eredményei alapján, megállapítható, hogy a rákbetegségben a test-lélek-környezet kapcsolatának több kérdése is megválaszolatlan ugyan, azonban jelentős iránymutató interakciós minták, kapcsolatok körvonalazódtak (Garssen 2004).

\footnotetext{
* Levelezô szerzô: Balog Piroska

Semmelweis Egyetem, Magatartástudományi Intézet

1089 Budapest, Nagyvárad tér 4.

E-mail: balopir@net.sote.hu
} 
Kutatásunkban azon pszicho-szociális tényezók együtthatásának vizsgálatára vállalkozunk, amelyek az onkopszichológiai tanulmányok kutatások és a gyakorlati tapasztalatok - szerint hatással lehetnek a pszichoszociális sérülékenység, az onkológiai mortalitás és a betegségfejlódésfelépülés alakulására. Ennek megfelelóen daganatos beteg nók körében a következő tényezóket vizsgáltuk: társas-családi támogatottság, optimizmus, a mútéttel kapcsolatos információ igénylése, állapot- és vonás-szorongás, illetve a stressz-szint alakulása.

\section{SZAKIRODALMI ÁTTEKINTÉS}

\section{Társas és családi támogatottság}

Pszicho-neuro-immunológiai vizsgálatok (Spiegel és mtsai 1998; KiecoltGlaser és Glaser 1999) eredményei rámutattak arra, hogy a neuroimmunológiai rendszerek közvetító - ennek részeként az NK (natural killer) sejtek modulátor - szerepet töltenek be a pszichoszociális tényezók és a daganatos betegség kialakulása között.

Levy és mtsai (1990) adatai szerint a jelentôs társas támogatottságról beszámoló vagy az érzelmi és instrumentális segítséget nyújtó interperszonális kapcsolatokat aktívan keresó, I. és II. stádiumban lévô melldaganatos betegek esetében magasabb NK-aktivitás figyelhetố meg. Rendszeres immunológiai utánkövetéses vizsgálataik is megerősítették, hogy az NK-múködés a visszaesés jelentôs elórejelzóje lehet, és az NK sejtek citotoxikus hatása a hosszabb tünetmentes állapottal asszociálható (Levy és mtsai 1991). A jelentôs társas támogatottság, a magas NK-aktivitás és a csökkent/lassult daganatfejlódés pozitív kapcsolatáról közöltek eredményeket Fawzy és munkatársai is (1993).

Korábbi kutatásaikban Levy és mtsai $(1985,1987)$ bizonyították, hogy a rosszindulatú melldaganatos nók NK sejtaktivitás-varianciájának 51\%át a társas támogatottság hiánya és két intrapszichés sajátosság, a páciens alkalmazkodási képessége és depressziós állapota határozza meg. Három hónapos utánkövetéses vizsgálatuk szerint az NK sejtaktivitás varianciájának 30\%-át az alacsony szociális támasz és a depresszió magyarázta.

A daganatos betegségek kialakulásának és prognózisának a társas támogatottsággal összefüggó kapcsolatáról, bizonyítható asszociációjáról hat követéses vizsgálat szolgáltat részletes adatokat (Maunsell és mtsai 1995; Cassileth és mtsai 1988; Reynolds és mtsai 1994, 2000; Rodrigue és mtsai 1999; Waxler-Morrison és mtsai 1991). 
Maunsell és munkatársai (1995) 224 mellrákos pácienst vizsgáltak a diagnózis megismerésének szakaszától. Azok a személyek, akiknek legalább egy bizalmas társas kapcsolatuk volt, 72\%-os túlélési esélyt mutattak, szemben a bizalmas kapcsolatok hiányáról beszámoló nókkel, akiknél a túlélési esély $56 \%$ volt. A túlélési esély 7 év után is a bizalmas kapcsolatok meglétének függvényében változott.

Cassileth és mtsai (1988) orvosi szempontból rossz prognózisú, különbözó típusú daganatos betegségben szenvedô páciensek csoportját vizsgálták 8 éves utánkövetéses vizsgálatukban. A vizsgálatban szerepló 204 rákbeteg körében az alacsony túléléssel a társas kapcsolatok hiánya-szegénysége és a házas családi állapot voltak asszociálhatók.

Reynolds és munkatársai (1994) a társas támogatottságot strukturális és funkcionális szempontból egyaránt vizsgálták. Interjúik során a kutatásban részt vevô daganatos betegek családi állapotát és a baráti kapcsolataik számát (szerkezeti elemzés), illetve az érzelmi és instrumentális támogatottság mértékét (funkcionális elemzés) egyaránt vizsgálták. Az 1011 fő́re kiterjedő, 6 éves követéses vizsgálat szerint a családi állapot és a baráti kapcsolatok száma nem befolyásolta az onkológiai mortalitást, a megtapasztalt érzelmi támogatottság azonban alacsonyabb onkológia mortalitással járt. A jelentôs társas-családi támogatottság és ennek minősége a daganatos betegség túlélésének szempontjából előrejelzó értékú Reynolds és mtsai (2000) 9 éves prospektív mérése alapján is.

A bizonytalan, kiszámíthatatlan, instabil szociális támogató rendszer csökkentette a Rodrigue és mtsai (1999) kutatásában megvizsgált 92 daganatos beteg túlélési esélyeit, miközben a több mint két elérhetó és gyakran igénybe vett baráti kapcsolat megléte, a többszintú társas támogatottság (család, munkatársak, orvosok, egyéb segítố szakemberek), illetve a nốtlenség/hajadonság Waxler-Morrison és mtsai (1991) prospektív vizsgálatában növelték a rákbetegek túlélési esélyeit.

Továbbá, a daganatos betegségek kialakulása és a társas kapcsolatok száma, illetve minősége, a társas izoláció és az onkológiai mortalitás összefüggéseit bizonyítja Reynolds és Kaplan (1990) elemzése is. A társas támogatottság nem-függó adatairól is beszámoltak, azonban megfeleló magyarázat nélkül. Azt találták, hogy azok a nók, akik társadalmilag elmagányosodva éltek és kevés baráti kapcsolatról számoltak be, nagyobb eséllyel lettek rákbetegek és gyakrabban haltak meg rákbetegégben. A férfiak esetében nem igazolták ezt az összefüggést. Ugyanakkor, a daganatos betegségben szenvedó férfiak esetében a rosszindulatú sejtfejlódés/növekedés jelentôsebb volt a sekélyes társadalmi kapcsolatokról beszámolók esetében. A megvizsgált nók esetében ezt a mintát nem sikerült megfigyelniük. 
Reynolds és Kaplan (1990) lényegében Berkman és Syme (1979) adatait dolgozták fel, amelyek azt mutatják, hogy a társas izoláció a dohányzással vagy a magas koleszterinszinttel összehasonlítható mértékben növeli a mortalitás általános veszélyét.

Összefoglalóan megállapíthatjuk, hogy a daganatos betegségek kialakulása, fejlődése és kimenetele kapcsán a kutatások nagy része a társas támogatottság jelentős szerepét bizonyítja, és részben sikerült meghatározni, hogy melyek a támogató jellegú társas és családi interakció legerósebb elórejelzó értékú formái a felépülés, illetve a tünetmentes állapot elérése, fenntartása szempontjából.

\section{Optimizmus}

Scheier és Carver (1992) szerint az optimizmus egy viszonylag stabil, általános hajlamosság arra, hogy pozitívan értékeljük az élet tapasztalatait és a jövố kihívásait. Az optimista egyének pozitívan élik meg társas és fizikai környezetüket, több erőfeszítést tesznek a problémák megelőzése és átkeretezése céljából, és hatékonyabban küzdenek meg betegségükkel.

Scheier és mtsai (1986) mellrákos páciensek esetében korrelációt találtak az optimizmus és a felépülési arány között. További kutatásaikban Scheier és Carver (1992) kiemelik, hogy az optimista páciensek kevésbé gyakran használják a tagadást a pesszimista betegekhez viszonyítva.

Szondy (2004) áttekintố tanulmánya hangsúlyozza, hogy a szituációspecifikus és attribúciós optimizmus jobban befolyásolja az immunmúködést, mint az általános vonás-optimizmus.

\section{Stressz- és szorongásszint}

A társas támogató rendszerek stresszoldó-védő hatása (buffering) az NK sejtek aktivitásában is nyomon követhető. Levy és munkatársai (1987, 1990, 1991) kutatási eredményei szerint a tartós pszichoszociális stressz csökkenti az NK sejtek aktivitását, daganatpusztító hatását, a jelentôs társas támogatottság azonban serkenti az NK sejtek citotoxikus hatékonyságát, és növeli számukat.

Tornling és mtsai (1994) 43 évig vizsgálták a stockholmi túzoltók körében a krónikus stresszhatás és az onkogenezis kapcsolatát. Eredményeik alapján megállapították, hogy a vizsgálati mintában, a daganatos betegségek prevalencia értéke nem volt nagyobb, mint az általános populációban. Kedvezó eredményeiket a munkakörnyezetben évek alatt 
kialakult támogató társas kapcsolatok morbiditást csökkentó hatásával magyarázták.

Hasonlóan Rosengren, Tibblin és Wilhelmsen (1991) 6935 férfi vizsgálata során nem találtak összefüggést a kérdezettek által megjelölt/megélt pszichológiai stressz-szint és az onkológiai mortalitás között $(\mathrm{OR}=0.8)$.

A daganatos betegség és a szorongás kapcsolatáról vitatott eredményeket szolgáltat Koenig és mtsai (1967) kutatása. A szerzók az MMPI módszert használva megállapították, hogy a rákbetegek kevésbé szorongóak a kórházban kezelt depressziós betegek, illetve a tuberkulózisban szenvedő páciensek csoportjához mérten. Pszichometriás vizsgálatuk adatait és összehasonlító elemzésük következtetését, illetve ezek empirikus érvényességét feltehetôen leginkább a felmérés folyamatában alkalmazott kutatási módszertan magyarázza. A vizsgálatban részt vevő 36 vastagbélrákos beteg esetében a daganatos betegség diagnózisának ismertetése és az MMPI mérés között átlagban 18 hónap telt el, amely időszak alatt valószínúleg kialakultak a személyfüggó, hatékony alkalmazkodási stratégiák, és ezek használata csökkenthette a szorongást.

\section{VIZSGÁLT POPULÁCIÓ ÉS ALKALMAZOTT MÓDSZEREK}

Kutatásunkban a Csíkszeredai Megyei Kórház Sebészeti Osztályán mútött nóket vizsgáltuk: 30 jóindulatú (benignus) melldaganattal, 30 malignus melldaganattal (karcinómával), és 30 vakbélgyulladás miatt mútött nót interjúvoltunk meg. A vizsgált nók életkora nem különbözött szignifikánsan $(\mathrm{p}=0,53)(1$. táblázat).

A kérdőívcsomagban szereplő skálák, kérdések a következók voltak:

Stressz-skála (Ross és Altmaier 1994): az élethez való viszonyulást vizsgálja, 29 kérdést tartalmaz, 1-4 pontozással (min. 29, max. 116 pont, Cronbach alpha 0,85).

Vonás- és állapotszorongás (Spielberger és mtsai 1970; Sipos és Sipos 1978): két alskálából áll (Cronbach alpha 0,86 és 0,87); 20-20 állítást tar-

1. táblázat. A vizsgált minta életkori megoszlása

\begin{tabular}{|l|c|c|c|}
\hline Diagnózis & Átlag & N & Szórás \\
\hline Vakbélmútét & 43,06 & 30 & 12,95 \\
\hline Jóindulatú daganat & 45,43 & 30 & 10,07 \\
\hline Rosszindulatú daganat & 46,27 & 30 & 11,30 \\
\hline Teljes minta & 44,86 & 120 & 11,76 \\
\hline
\end{tabular}


talmaz mindkét alskála arra vonatkozóan, hogy a személy általában, illetve éppen most hogyan érzi magát.

Mútétre Vonatkozó Optimizmus Skála: 10 kérdést tartalmaz, a kérdések 0-3 pontozásúak (min. 1, max. 30 pont). (1. melléklet; Cronbach alpha 0,77 .)

Mútéttel Kapcsolatos Információk Igénylése Skála: 10 kérdést tartalmaz, a válaszok 0-2 pontozásúak (min. 1, max. 20 pont). (2. melléklet; Cronbach alpha 0,76.)

A családi támogatottságot két kérdéssel mértük: 1),'Szeretném, ha a családom többet törôdne jóllétemmel.” 2) „Családomban magányosnak érzem magam." Mindkét kérdést hétfokú skálán értékelték: 1. egyáltalán nem jellemzó, 2. nem jellemzó, 3. csak kis mértékben jellemzô, 4. féligmeddig jellemzó, 5. viszonylag jellemzó, 6. jellemzó, 7. teljes mértékben jellemzó.

A statisztikai elemzést az SPSS 9.0 program segítségével végeztük el. A használt módszer: General Linear Model, a modellben szerepló kovariánsok az életkor és a szocio-ökonómiai státus voltak.

\section{EREDMÉNYEK}

\section{Életkor, szocio-ökonómiai státus}

A szocio-ökonómiai státust a következóképpen kódoltuk: SES1: jelenleg nem aktív (tanuló, nyugdíjas, munkanélküli), illetve jelenleg munkásként - szakképesítés nélkül - dolgozó; SES2: szakképesítéssel rendelkezó, szolgáltatóiparban dolgozó (pl. kozmetikus, pincér); SES3: technikusi, felsófokú szakképzettséggel rendelkezó (pl. asszisztens, könyvtáros); SES4: fóiskolai, egyetemi végzettséggel rendelkezó (pl. pedagógus).

A szocio-ökonómiai státus függvényében az egyes betegségek elófordulási gyakorisága szignifikánsan különbözött $(\mathrm{p}=0,03)$; a rosszindulatú daganatos betegek leginkább a legalacsonyabb szocio-ökonómiai státusúak köréból kerültek ki (2. táblázat). Jóllehet a kutatásban részt vevó

2. táblázat. Az egyes betegségek elófordulási gyakorisága szocio-ökonómiai státus szerint

\begin{tabular}{|l|c|c|c|r|}
\hline Diagnózis & SES1 & SES2 & SES3 & \multicolumn{1}{|c|}{ SES4 } \\
\hline Vakbélmútét & $45,1 \%$ & $45,2 \%$ & $3,2 \%$ & $6,5 \%$ \\
\hline Jóindulatú daganat & $43,3 \%$ & $30,1 \%$ & $13,3 \%$ & $13,3 \%$ \\
\hline Rosszindulatú daganat & $70,0 \%$ & $10,0 \%$ & $16,7 \%$ & $3,3 \%$ \\
\hline
\end{tabular}


nók átlagéletkora nem különbözött ( $\mathrm{p}=0,53)$, számításainkban az életkort, a szocio-ökonómiai státussal együtt mint kovariánst, mindig figyelembe vettük.

\section{Szorongás-, stressz-szint a vizsgált csoportokban}

Hipotézisünkkel ellentétben (miszerint mind az aktuális, mind a vonásszorongás, valamint a stressz növekszik a diagnózis súlyosságával, vagyis legkisebb a vakbélmútét elótt állóknál, legnagyobb a rosszindulatú daganatos betegeknél), a vonás-szorongást és a stressz-szintet illetóen nem találtunk szignifikáns eltérést a vizsgált csoportokban. Az aktuális szorongás viszont a rosszindulatú daganatos betegek között volt a legnagyobb. Szignifikánsan magasabb volt mind a vakbélmútét elôtt állókénál $(\mathrm{p}=0,01)$, mind a jóindulatú daganatos betegekénél $(\mathrm{p}=0,03)(3-5$. táblázat).

Ami a mútéttel kapcsolatos optimizmust illeti, a legkevésbé optimisták a rosszindulatú daganatos betegek voltak, bár itt a különbség csak tendenciális $(\mathrm{p}=0,08)$ (6. táblázat).

3. táblázat. A Stressz-skála átlagértékei a vizsgált csoportokban

\begin{tabular}{|l|c|c|c|}
\hline \multirow{2}{*}{ Diagnózis } & \multirow{2}{*}{ Átlag } & \multicolumn{2}{|c|}{$95 \%$-os konfidencia intervallum } \\
\cline { 3 - 4 } & & alsó határ & felsó határ \\
\hline Vakbélmútét & 61,13 & 57,40 & 64,86 \\
\hline Jóindulatú daganat & 60,07 & 56,18 & 63,96 \\
\hline Rosszindulatú daganat & 59,85 & 56,04 & 63,66 \\
\hline
\end{tabular}

4. táblázat. A vonás-szorongás alskála átlagértékei a vizsgált csoportokban

\begin{tabular}{|l|c|c|c|}
\hline \multirow{2}{*}{ Diagnózis } & \multirow{2}{*}{ Átlag } & \multicolumn{2}{|c|}{$95 \%$-os konfidencia intervallum } \\
\cline { 3 - 4 } & & alsó határ & felsó határ \\
\hline Vakbélmútét & 46,58 & 43,49 & 49,67 \\
\hline Jóindulatú daganat & 47,56 & 44,50 & 50,62 \\
\hline Rosszindulatú daganat & 48,53 & 45,53 & 51,53 \\
\hline
\end{tabular}

5. táblázat. Az aktuális szorongás alskála átlagértékei a vizsgált csoportokban

\begin{tabular}{|l|c|c|c|}
\hline \multirow{2}{*}{ Diagnózis } & \multirow{2}{*}{ Átlag } & \multicolumn{2}{|c|}{$95 \%$-os konfidencia intervallum } \\
\cline { 3 - 4 } & & alsó határ & felső határ \\
\hline Vakbélmútét & 48,25 & 44,86 & 51,63 \\
\hline Jóindulatú daganat & 49,34 & 45,84 & 52,85 \\
\hline Rosszindulatú daganat & 54,70 & 51,20 & 58,21 \\
\hline
\end{tabular}


6. táblázat. A Mútétre Vonatkozó Optimizmus Skála átlagértékei

\begin{tabular}{|l|c|c|c|}
\hline \multirow{2}{*}{ Diagnózis } & \multirow{2}{*}{ Átlag } & \multicolumn{2}{|c|}{$95 \%$-os konfidencia intervallum } \\
\cline { 3 - 4 } & & alsó határ & felsố határ \\
\hline Vakbélmútét & 18,09 & 16,38 & 19,80 \\
\hline Jóindulatú daganat & 18,13 & 16,38 & 19,89 \\
\hline Rosszindulatú daganat & 15,96 & 14,21 & 17,71 \\
\hline
\end{tabular}

Nem találtunk különbséget az igényelt információ mennyiségét illetôen a vizsgált csoportokban (7. táblázat).

7. táblázat. A Mútéttel Kapcsolatos Információk Igénylése Skála átlagértékei

\begin{tabular}{|l|c|c|c|}
\hline \multirow{2}{*}{ Diagnózis } & \multirow{2}{*}{ Átlag } & \multicolumn{2}{|c|}{$95 \%$-os konfidencia intervallum } \\
\cline { 3 - 4 } & & alsó határ & felsó határ \\
\hline Vakbélmútét & 14,41 & 13,10 & 15,72 \\
\hline Jóindulatú daganat & 14,26 & 12,92 & 15,60 \\
\hline Rosszindulatú daganat & 13,87 & 12,54 & 15,21 \\
\hline
\end{tabular}

A családi támogatottság vizsgálatához elkülönítettük azokat, akik elégedettek családjuk támogatásával, és azokat, akik több támogatást igényelnének családjuk részéról. A „családja támogatásával elégedett” kategóriához összevontuk az 1, 2, 3, vagyis az egyáltalán nem jellemző, nem jellemző és csak kis mértékben jellemzó válaszokat (vagyis akikre nem jellemző, hogy több törődést igényelnének, mint amennyit kapnak). A "családjuk támogatásával elégedetlen" kategóriához összevontuk a 4, 5, 6, 7, vagyis a félig-meddig jellemzó, viszonylag jellemzó, jellemzó és a teljes mértékben jellemzó válaszokat.

Hasonlóan, a "családjában nem magányos" kategóriához összevontuk az 1, 2, 3, vagyis az egyáltalán nem jellemzó, nem jellemzó és csak kis mértékben jellemzó válaszokat. A „családjában magányos” kategóriához pedig összevontuk a 4, 5, 6, 7, vagyis a félig-meddig jellemzó, viszonylag jellemzó, jellemzố és a teljes mértékben jellemzó válaszokat.

E kategóriák mentén felosztva a vizsgált csoportokat, hat alcsoportot hasonlítottunk össze: a családjuk támogatásával elégedett vakbélmútét elôtt állók, a családjuk támogatásával elégedetlen vakbélmútét elótt állók, valamint a családjuk támogatásával elégedett, illetve elégedetlen jóindulatú, illetve rosszindulatú daganatos betegeket. Aszerint, hogy a családjában magányosnak érzi-e magát a beteg, illetve nem, szintén hat alcsoportot hasonlítottunk össze, a fentieknek megfelelóen.

Eredményeink szerint a legmagasabb volt az aktuális szorongás-szint a családjuk támogatásával elégedetlen, rosszindulatú daganatos betegek 
esetében. Az ô aktuális szorongásszintjük minden más csoporténál szignifikánsan magasabbnak bizonyult $(\mathrm{p}=0,003)(1$. ábra) .

Másik összehasonlításunkban ugyancsak a családjukban magukat magányosnak érzó, rosszindulatú daganatos betegek aktuális szorongásszintje bizonyult a legmagasabbnak $(\mathrm{p}=0,0001)$. Az ó szorongásszintjük

$\square$ vakbélmütött $\square$ jóindulatú daganatos $\square$ rosszindulatú daganatos

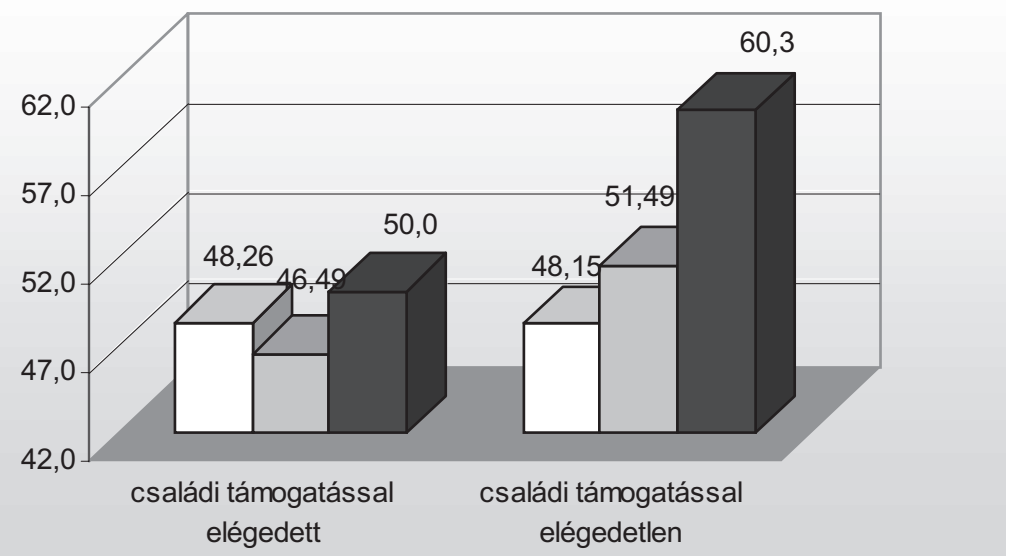

1. ábra. Az aktuális szorongás a családi támogatottsággal való elégedettség függvényében

$\square$ vakbélmütött $\square$ jóindulatú daganatos $\square$ rosszindulatú daganatos

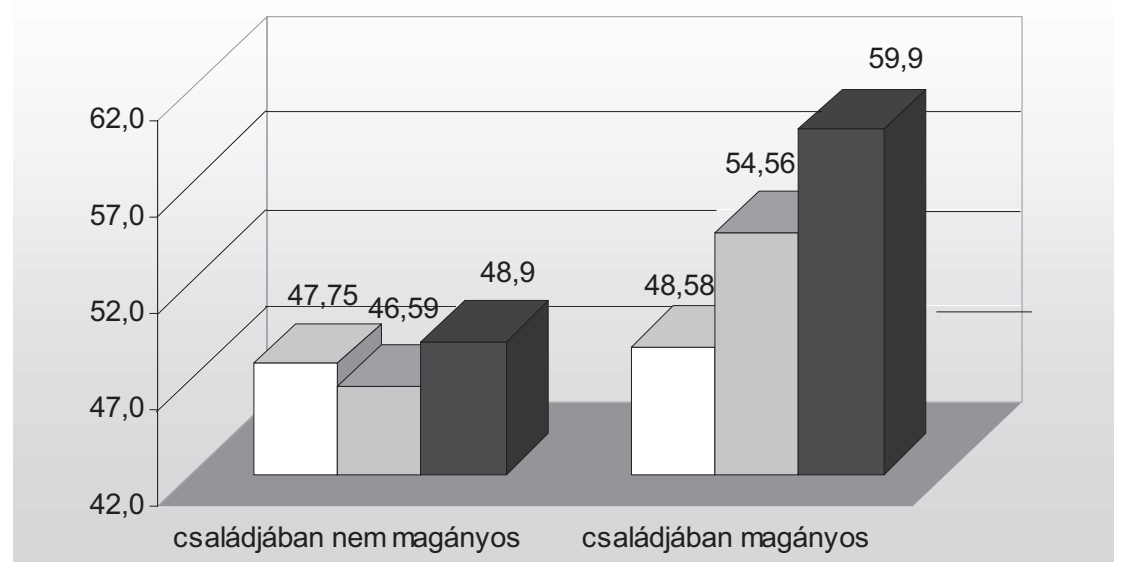

2. ábra. Az aktuális szorongás a családon belüli magányérzet függvényében 


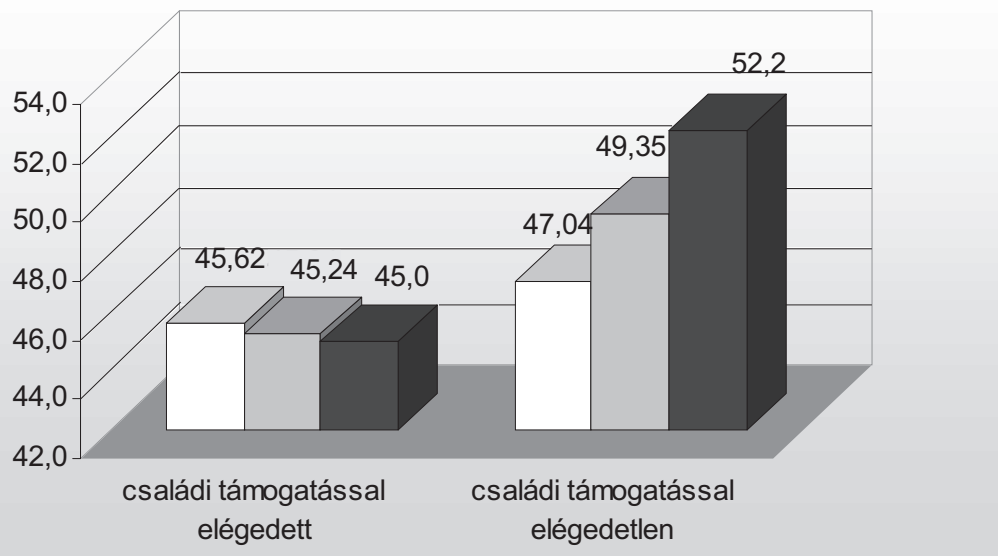

3. ábra. Vonás-szorongás a családi támogatottsággal való elégedettség függvényében

$\square$ vakbélmütött $\square$ jóindulatú daganatos $\square$ rosszindulatú daganatos

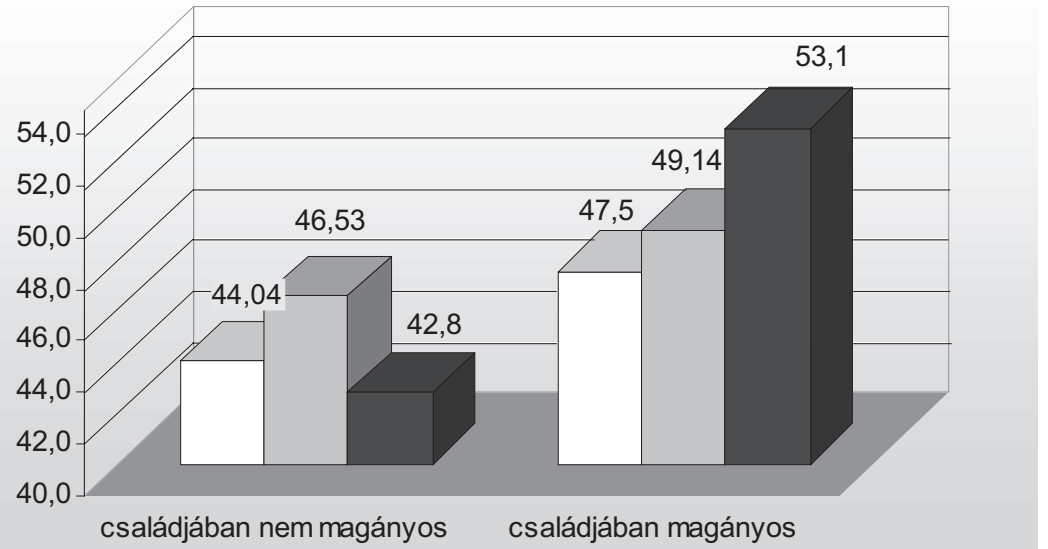

4. ábra. Vonás-szorongás a családon belüli magányérzet függvényében

csak azon jóindulatú daganatos betegekétól nem különbözött szignifikánsan, akik szintén magányosnak érezték magukat a családjukban (2. ábra).

Hasonlóképpen alakult a vonás-szorongás is. A családjuk támogatásával elégedetlen, rosszindulatú daganatos betegekre volt jellemzó a legmagasabb vonás-szorongás. Az ố vonás-szorongás szintjük csak a csa- 
ládjuk támogatásával szintén elégedetlen, jóindulatú daganatos betegekétôl nem különbözött szignifikánsan (3. ábra).

A családjukban magukat magányosnak érzó, rosszindulatú daganatos betegek vonás-szorongása minden más csoporténál nagyobbnak bizonyult $(\mathrm{p}=0,01)$, kivételt csak azok a jóindulatú daganatos betegek képeztek, akik magukat szintén magányosnak érezték a családjukban (4. ábra).

Hasonlóképpen alakult a stressz-szint, bár itt csak két szignifikáns különbséget találtunk. Az nem meglepó, hogy azok a rosszindulatú daganatos betegek, akik családjuk körében magányosnak érzik magukat, szignifikánsan magasabb stressz-szintról számoltak be, mint azok a vakbélmútét elótt állók, akik családjukban nem érzik magányosnak magukat; az viszont kiemelendó, hogy ugyancsak szignifikánsan magasabb stressz-szintról számoltak be, mint azok az ugyancsak rosszindulatú daganatos betegek, akik családjukban nem érzik magányosnak magukat (5-6. ábra).

A családi támogatottság megléte, illetve hiánya szempontjából érdekesen alakult a mútéttel kapcsolatos optimizmus is. A legkevésbé optimisták a rosszindulatú daganatos betegek voltak, és közülük is azok, akik családjuk támogatásával elégedetlenek. Ők minden más csoportnál alacsonyabb optimizmusról számoltak be $(\mathrm{p}=0,04)$, bár optimizmusuk csak tendenciálisan különbözött a családjuk támogatásával elégedett, rosszindulatú daganatos betegekétól $(\mathrm{p}=0,08)(7$. ábra) .

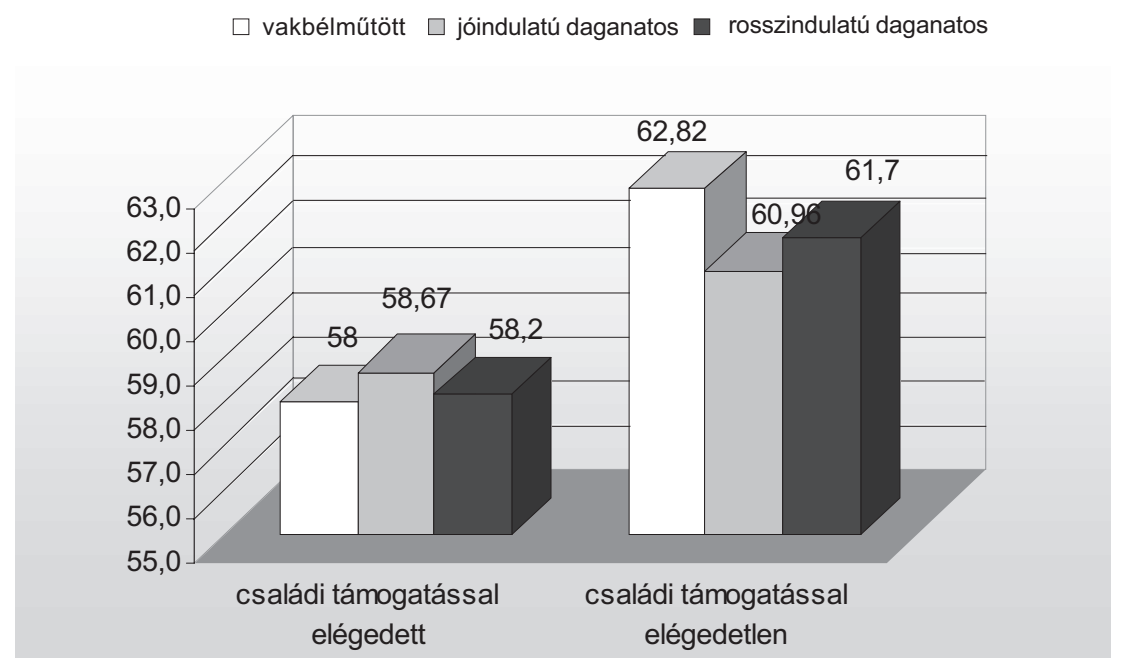

5. ábra. Stressz-szint a családi támogatottsággal való elégedettség függvényében 


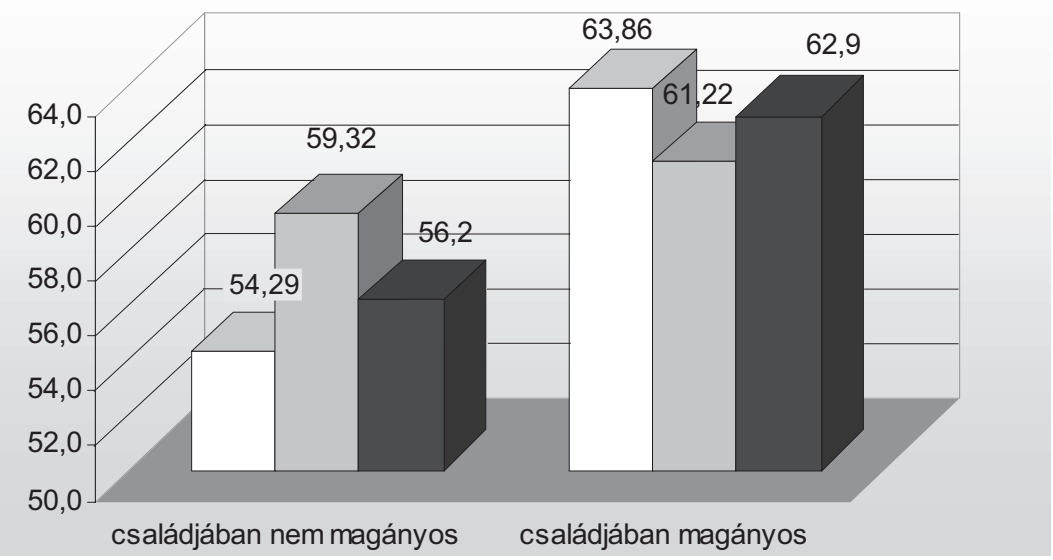

6. ábra. Stressz-szint a családon belüli magányérzet függvényében

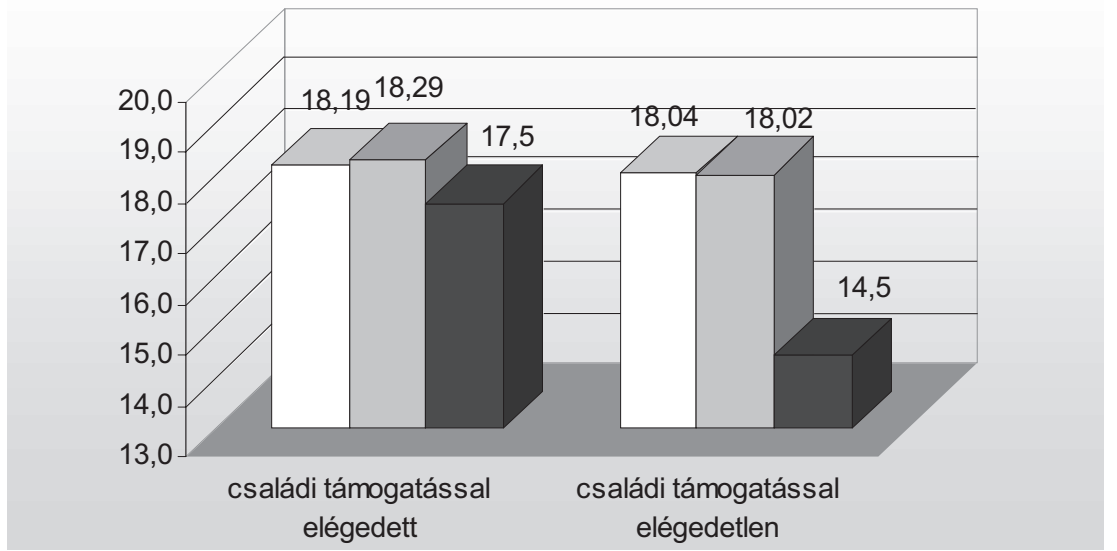

7. ábra. Mútéttel kapcsolatos optimizmus a családi támogatottsággal való elégedettség függvényében

A magukat családjukban magányosnak érzó, rosszindulatú daganatos betegek optimizmusa viszont csak a magukat családjukban szintén magányosnak érzó, jóindulatú daganatos betegekétól nem különbözött szignifikánsan, az összes többi csoportnál viszont szignifikánsan alacsonyabb $(\mathrm{p}=0,004)$ optimizmusról számoltak be (8. ábra). 


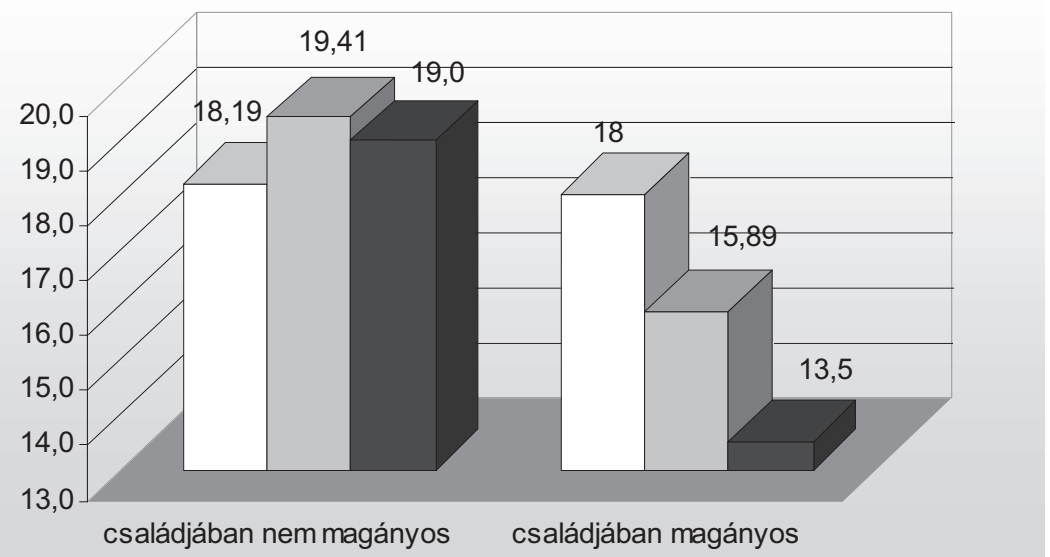

8. ábra. Mútéttel kapcsolatos optimizmus a családon belüli magányérzet függvényében

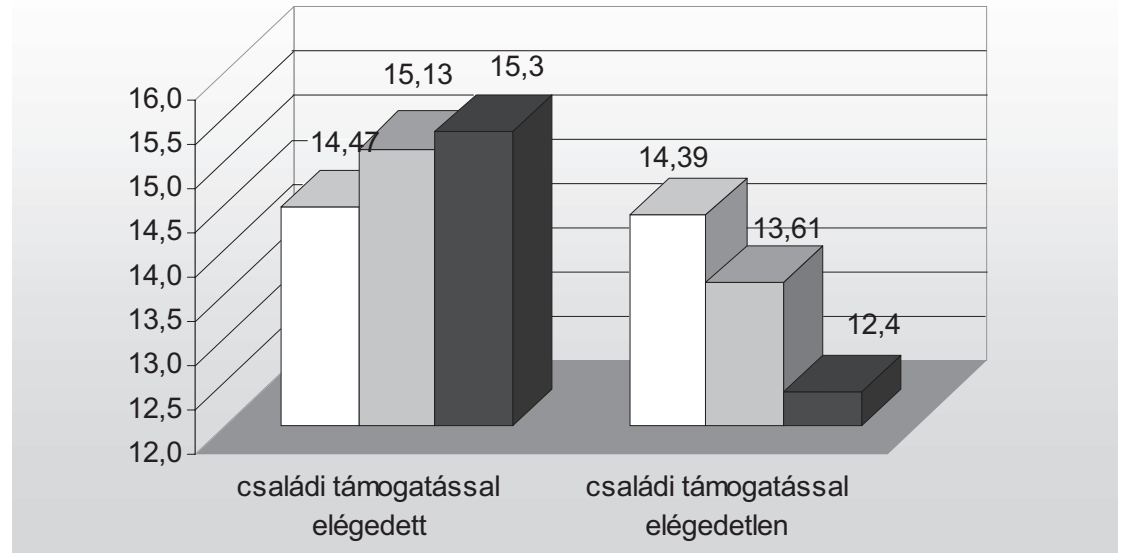

9. ábra. Mútéttel kapcsolatos információ igénylése a családi támogatottsággal való elégedettség függvényében

A vakbélmútét elótt állók, illetve a jóindulatú daganatos betegek akkor is optimistábbak voltak, ha családjuk támogatásával elégedetlenek voltak, illetve ha családjukban magányosnak érezték magukat. Az ô optimizmusszintjükön nem sokat változtatott a családi támogatottság. Kiemelendő viszont az az eredmény, hogy a családjukban magukat nem ma- 


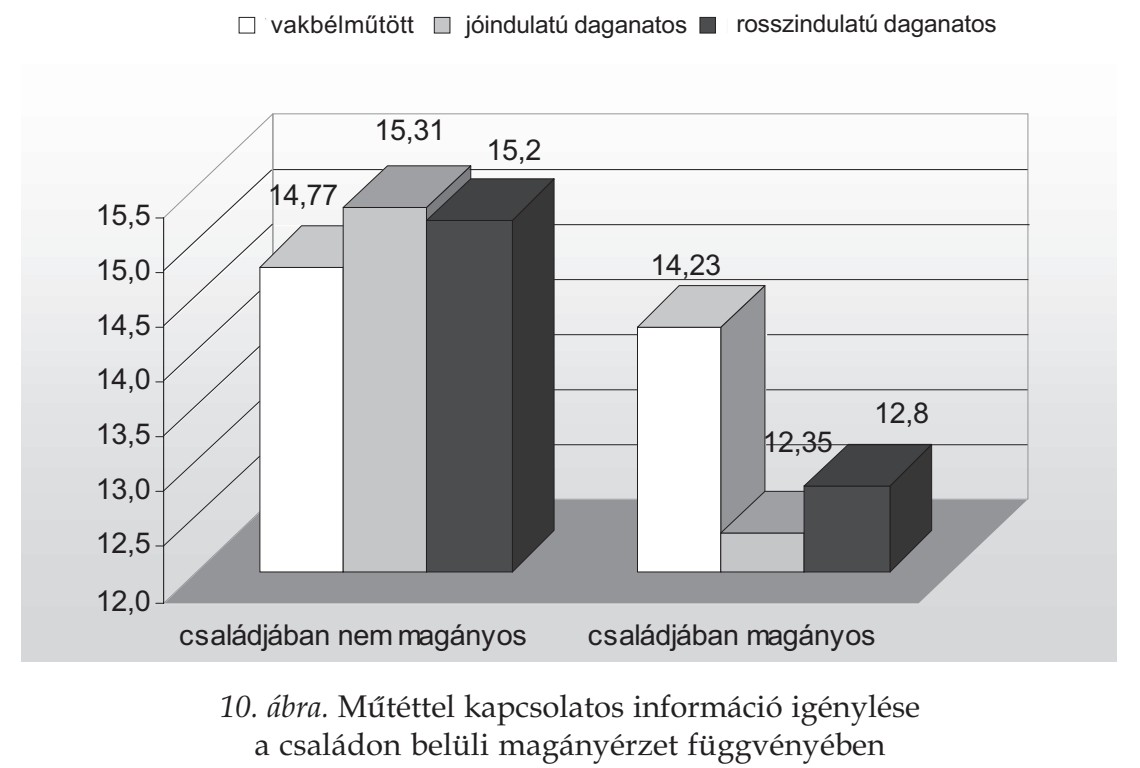

gányosnak érzó, rosszindulatú daganatos betegek optimizmusszintje magasabb, mint a vakbélmútét elótt állóké (!).

A mútéttel kapcsolatos információ igénylése is különbözött a családi támogatottság függvényében. Azok a rosszindulatú daganatos betegek, akik úgy érzik, hogy családjuktól kevés támogatást kapnak, illetve akik magányosak a családjukban, szignifikánsan kevesebb információt igényelnek, mint azok a daganatos betegek, akik elégedettek családjuk támogatásával ( $\mathrm{p}=0,02$, illetve $\mathrm{p}=0,04)(9-10$. ábra) .

Itt is kiemelendónek tartjuk azt az eredményt, hogy a legtöbb információt azok a rosszindulatú daganatos betegek igényelték, akik családjuk támogatásával elégedettek.

Összefoglalva: az általunk vizsgált daganatos betegek körében egyértelmú és statisztikailag szignifikáns összefüggést találtunk a családi támogatottság, a vonás- és állapotszorongás-szint, illetve a stressz-szint között. Ugyancsak összefüggést találtunk a pszichoszociális sérülékenység szempontjából legveszélyeztetettebb csoportban (rosszindulatú daganatos betegek esetében) az egészségvédó megküzdési stratégiák - az optimizmus és információkérés, -igénylés -, valamint a családi támogatottság között.

A családi támogatottsággal való elégedetlenség nagyobb stresszt és szorongást, kevesebb optimizmust és csökkent információbefogadási képességet, korlátozott megküzdési potenciált jelentett. A vakbélmútét elótt 
állók szorongás- és stressz-szintje, valamint a mútéttel kapcsolatos optimizmus és az igényelt információ mennyisége a vizsgált csoportban nem mutatott összefüggést a családi támogatottsággal.

\section{KÖVETKEZTETÉSEK}

Vakbélmútét elótt álló, valamint daganatos nók pszichoszociális sérülékenységét vizsgáltuk a családi támogatottság összefüggésében. Eredményeink arra mutattak, hogy a családi kapcsolatok minósége, a beteg családi támogatottsága fontos szerepet játszik a mútéttel kapcsolatos stresszés szorongás-szint alakulásában, és minél magasabb az átélt stressz, ennek csökkentésében annál fontosabbá válik a családi támogatás. Eredményeink felhívják a figyelmet a daganatos betegek pszichoszociális háttértényezőinek vizsgálatára, valamint a családi támogatottság erôsítésének fontosságára.

\section{Irodalom}

Berkman, L. F., Syme, S.L. (1979): Social networks, host resistance, and mortality: a nineyear follow-up study of Alameda County residents. American Journal of Epidemiology, 109: 186-204.

Cassileth, B. R., Walsh, W. P., Lusk, E. J. (1988): Psychosocial correlates of cancer survival: a subsequent report 3 to 8 years after cancer diagnosis. Journal of Clinical Oncology, 6: 1753-1759.

Fawzy, F. I., Fawzy N. W., Hyun C. S., Elashoff, R., Guthrie, D., Fahey, J. L., Morton, D. L. (1993): Malignant melanoma. Effects an early structured psychiatric intervention, coping, and effective state on recurrence and survival 6 years later. Archives of General Psychiatry, 50 (9): 681-689.

Garssen, B. (2004): Psychological factors and cancer development: evidence after 30 years of research. Clinical Psychology Review, 24: 315-338.

Kiecolt-Glaser, J. K., Glaser, R. (1999): Psychoneuroimmunology and cancer: fact or fiction? European Journal of Cancer, 35 (11): 1603-1607.

Koenig, R. R., Levin, S. M., Brennan, M. J. (1967): The emotional status of cancer patients as measured by psychological test. Journal of Chronic Disease, 20: 923-930.

Levy S. M., Herberman, R. B., Maluish, A. M., Schlien, G., Lippman M. (1985): Prognostic risk assessment in primary breast cancer by behavioural and immunological parameters. Health Psychology, 4: 99-113.

Levy S. M., Herberman, R., Lippman M., D’Angelo, T. (1987): Correlation of stress factors with sustained depression of natural killer cell activity and predicted prognosis in patients with breast cancer. Journal of Clinical Oncology, 5: 348-353.

Levy, S. M., Herberman, R. B. Whiteside, T., Sanzo, K., Lee J., Kirkwood J. (1990): Perceived social support and tumor estrogen/progesterone receptor status as predictors of natural killer cell activity in breast cancer patients. Psychosomatic Medicine, 52 (1): 73-85. 
Levy, S. M., Herberman, R. B., Lippman, M., D’Angelo, T., Lee, J. (1991): Immunological and psychosocial predictors of disease recurrence in patients with early-stage breast cancer. Behavioral Medicine, 17 (2): 67-75.

Maunsell, E., Brisson, J., Deschenes, L. (1995): Social support and survival among women with breast cancer. Cancer, 76: 631-637.

Reynolds, P., Boyd, P. T., Blacklow, R. S., Jackson, J. S., Greenberg, R. S., Austin, D. F., Chen, V. W., Edwards, B. K. (1994): The relationship between social ties and survival among black and white breast cancer patients. Cancer Epidemiology, Biomarkers and Prevention, 3: 253-259.

Reynolds, P., Hurley, S., Torres, M., Jackson, J., Boyd, P., Chen, V. W. (2000): Use of coping strategies and breast cancer survival: results from the Black/White Cancer Survival Study. American Journal of Epidemiology, 152: 940-949.

Reynolds, P., Kaplan, G. A. (1990): Social connections and risk for cancer. Prospective evidence from the Alameda County study. Behavioral Medicine, 16: 101-110.

Rodrigue, J. R., Pearman, T. P., Moreb, J. (1999): Morbidity and mortality following bone marrow transplantation: Predictive utility of pre-BMT affective functioning, compliance, and social support stability. International Journal of Behavioral Medicine, 6: 241-254.

Rosengren, A., Tibblin, G., Wilhelmsen, P. (1991): Self-perceived psychological stress and incidence of coronary artery disease in middle-aged men. American Journal of Cardiology, 68: 1171-1175.

Ross, R. R., Altmaier, E. M. (1994): Intervention in Occupational Stress. Thousand Oaks, Sage Publications Ltd., California.

Scheier, M. S., Carver, C. S. (1992) Effects of optimism on psychological and physical wellbeing. Cognitive Therapy and Research, 3: 1-18.

Scheier, M., Weintraub, J., Carver, C. (1986) Coping with stress, divergent strategies of optimism and pessimism. Journal of Personality and Social Psychology, 51: 1257-1264.

Sipos, K., Sipos, M. (1978): The Development and Validation of the Hungarian Form of the STAI. In Spielberger, C. D., Diaz-Guerrero, R. (eds.): Cross-Cultural Anxiety. Hemisphere Publishing Corporation, Washington-London, 51-61.

Speigel, D., Sephton, S. E., Terr, A. I., Stites, D. P. (1998): Effects of psychosocial treatment in prolonging cancer survival may be mediated by neuroimmune pathways. Annals of the New York Academy of Science, 840: 674-683.

Spielberger, C. D., Gorsuch, R. L., Lushene, R. E. (1970): Manuel for State-Trait Anxiety Inventory. Consulting Psychologist Press, Palo Alto, California.

Szondy M. (2004): Optimizmus és immunfunkciók. Mentálhigiéné és Pszichoszomatika, 5 (4): 301-319.

Tornling, G., Gustavsson, P., Hogstedt, C. (1994): Mortality and cancer incidence in Stockholm fire fighters. American Journal of Industrial Medicine, 25: 219-228.

Waxler-Morrison, N., Hislop, T. G., Mears, B., Kan, L. (1991): Effects of social relationships on survival for women with breast cancer: a prospective study. Social Science $\mathcal{E}$ Medicine, 33: 177-183. 


\section{Mellékletek}

1. melléklet. Mútétre Vonatkozó Optimizmus Skála (Cronbach alpha =0,77)

\begin{tabular}{|l|c|c|c|c|}
\hline & $\begin{array}{c}\text { Nem } \\
\text { hiszem }\end{array}$ & Remélem & $\begin{array}{c}\text { Bízom } \\
\text { benne }\end{array}$ & $\begin{array}{c}\text { Meggyó- } \\
\text { zódésem }\end{array}$ \\
\hline 1. A mútét megoldja a problémámat. & 0 & 1 & 2 & 3 \\
\hline 2. Fájdalommentes lesz a mútét. & 0 & 1 & 2 & 3 \\
\hline 3. Ébredésem könnyú lesz. & 0 & 1 & 2 & 3 \\
\hline 4. Mútét után kapok fájdalomcsillapítót. & 0 & 1 & 2 & 3 \\
\hline $\begin{array}{l}\text { 5. A mútéti terület gyógyulása } \\
\text { komplikációmentes lesz. }\end{array}$ & 0 & 1 & 2 & 3 \\
\hline $\begin{array}{l}\text { 6. A mútéti heg esztétikus lesz. } \\
\text { 7. Mútét után tovább folytathatom } \\
\text { megszokott életvitelemet. }\end{array}$ & 0 & 1 & 2 & 3 \\
\hline $\begin{array}{c}\text { 8. A kórházban való tartózkodásom } \\
\text { rövid idótartamú lesz. }\end{array}$ & 0 & 1 & 2 & 3 \\
\hline $\begin{array}{c}\text { 9. A kórteremben hasonló betegségben } \\
\text { szenvedó betegek lesznek. }\end{array}$ & 0 & 1 & 2 & 3 \\
\hline $\begin{array}{c}\text { 10. Ismerek hasonló diagnózissal operált } \\
\text { betegeket, akik már jól érzik magukat. }\end{array}$ & 0 & 1 & 2 & 3 \\
\hline
\end{tabular}

2. melléklet. Mútéttel Kapcsolatos Információk Igénylése Skála (Cronbach alpha = 0,76)

\begin{tabular}{|l|c|c|c|}
\hline & $\begin{array}{c}\text { Nem } \\
\text { akarom } \\
\text { tudni }\end{array}$ & $\begin{array}{c}\text { Esetleg } \\
\text { megkér- } \\
\text { dezném }\end{array}$ & $\begin{array}{c}\text { Minden feltétel } \\
\text { mellett tudni } \\
\text { szeretném }\end{array}$ \\
\hline 1. Fájni fog a mútét? & 0 & 1 & 2 \\
\hline 2. Merülhet-e fel komplikáció? & 0 & 1 & 2 \\
\hline 3. A mútéti heg esztétikus lesz? & 0 & 1 & 2 \\
\hline $\begin{array}{c}\text { 4. Mennyi idót kell a kórházban } \\
\text { tartózkodnom? }\end{array}$ & 0 & 1 & 2 \\
\hline 5. Mire kell vigyáznom mútét után? & 0 & 1 & 2 \\
\hline $\begin{array}{c}\text { 6. Érzéstelenítéssel lesz a mútéti } \\
\text { beavatkozás? }\end{array}$ & 0 & 1 & 2 \\
\hline 7. Mi idézte eló a betegségemet? & 0 & 1 & 2 \\
\hline $\begin{array}{c}\text { 8. Mennyi idó után folytathatom } \\
\text { a megszokott életvitelemet? }\end{array}$ & 0 & 1 & 2 \\
\hline $\begin{array}{c}\text { 9. Milyen hatással lesz a mútét } \\
\text { a szexuális életemre? }\end{array}$ & 0 & 1 & 2 \\
\hline $\begin{array}{c}\text { 10. Lesznek a kórteremben hasonló } \\
\text { betegségben szenvedó betegek? }\end{array}$ & 0 & 1 & \\
\hline
\end{tabular}


Köszönetnyilvánítás. Köszönetünket fejezzük ki Tóke Ágnesnek, a Csíkszeredai Megyei Kórház Sebészeti Osztály főasszisztensének, aki az interjúkat felvette.

\section{BALOG, PIROSKA - DÉGI, L. CSABA \\ FAMILY SUPPORT DECREASING PSYCHOSOCIAL VULNERABILITY IN WOMEN WITH CANCER}

Aim: There is substantial evidence in psychosomatic literature linking the role of social support in coping with chronic diseases. Studies related to the quality of family relationships, and family supports are rare.

Methods: Women patients in the County Hospital, Surgery Ward, Csíkszereda, were interviewed: 30 women with appendicitis, 30 women with benign breast cancer, and 30 women with malign breast cancer. The age of women did not differed significantly. Women with malign breast cancer were mostly with the lowest socio-economical status. Anxiety, stress, optimism and the need of information related to surgery were measured by scales and questions related to family support were included in the study.

Results: Women with malign breast cancer reported the highest anxiety, and stress. Family support played an important role decreasing stress and anxiety, and increasing optimism and the amount of information related to surgery.

Conclusion: The quality of family relationships plays an important role in decreasing stress and anxiety. The higher the stress, the more important the family support is.

Keywords: women, cancer, stress and anxiety, optimism, information related to surgery, family support 